\title{
Dexpanthenol Mouthwash
}

National Cancer Institute

\section{Source}

National Cancer Institute. Dexpanthenol Mouthwash. NCI Thesaurus. Code C96233.

A mouthwash containing 5\% dexpanthenol, the alcoholic analogue of the dextrorotatory isomer of pantothenic acid with potential antimucositis activity. Although the exact mechanism remains to be elucidated, upon rinsing with this solution dexpanthenol is converted to pantothenic acid (vitamin B5) which is required for coenzyme A synthesis as well as for the metabolism of proteins, carbohydrates, and fats. Coenzyme $A$ is involved in fatty acids and sphingolipids synthesis crucial for cell membrane integ rity. This mouthwash may have a protective and healing effect on the oral mucosa, may improve hydration and may potentially prevent or reduce radiation/chemotherapy-induced mucositis. 